\title{
STUDY THE PATTERN OF MOBILE PHONE USAGE IN MEDICAL
} STUDENTS

\author{
Viren B. Kariya ${ }^{1}$, Lalit C. Ratanpara *2.
}

${ }^{1}$ Associate Professor, Department of Anatomy, PDU Govt. Medical College, Rajkot, Gujarat, India.

${ }^{* 2}$ Tutor, Department of Anatomy, PDU Govt. Medical College, Rajkot, Gujarat, India.

\section{ABSTRACT}

Objective: Mobile technology has influenced the way of living across all segments of society and has raised concern about its electromagnetic waves. Hence, the present study gives emphasis on investigating the pattern of mobile phone usage among undergraduate medical students and their perception and awareness regarding negative health effects due to excessive exposure of electromagnetic waves.

Methods: A cross sectional study was conducted among 170 UG students of PDU Govt. Medical College, Rajkot, Gujarat, India. Data were collected by pre-tested questionnaire in Google form and analysed using MS Excel software.

Results: Out of total students participated in the study, 103 were males and 67 were females; Average time spent using mobile phones was 3.75 hours/day; $51.2 \%$ students kept their mobile phone ON during lecture; $75.9 \%$ also stated that they were aware of health hazards due to exposure to electromagnetic waves; $27.6 \%$ students agreed that their sleep is suffered due to use of mobile phone.

Conclusion: the outcomes of this study confirms that there is excessive use of mobile phone among medical students. Regulatory bodies should form some specific regulations and guidelines regarding mobile phone usage in classroom. Further, it is also required to anticipate long term health hazards considering its overuse among young adults.

KEY WORDS: Mobile Phone, Electromagnetic Waves, Mobile Phone Addiction, Medical Students, Health Hazards, Cell Phone Radiation.

Address for Correspondence: Dr. Lalit C. Ratanpara, Tutor, Department of Anatomy, PDU Govt. Medical College, Rajkot, Gujarat, India. E-Mail: akshar.ratanpara@gmail.com

Access this Article online

Quick Response code

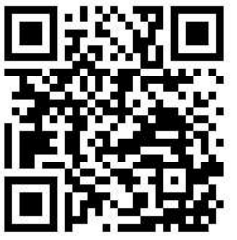

DOI: $10.16965 /$ ijar.2019.204

Journal Information

International Journal of Anatomy and Research

ICV for 2016 ISSN (E) 2321-4287 | ISSN (P) 2321-8967

https://www.ijmhr.org/ijar.htm

DOI-Prefix: https://dx.doi.org/10.16965/ijar

\section{Article Information}

Received: 19 Apr 2019

Peer Review: 26 Apr 2019

Revised: None
Accepted: 10 Jun 2019

Published (0): 05 Jul 2019

Published (P): 05 Jul 2019

\section{INTRODUCTION}

What was previously stated as an 'Idiot box'The Television, has been largely replaced by something else amongst the young adults and it is becoming the only smartest thing they have. And it is named - 'A smart phone'.

As all other gadgets are being swallowed by new generation black hole (the smart phone) with easy and affordable access to the internet; makes it the most seeking and lucrative thing in market. The youth is the most vulnerable and lenient target to get addicted. Technology is a double-edged sword and unless there is a check point; the negative aspects will always prevail and dominate. For students, the finest means to limit excessive usage of smartphones can be self-motivation by creating awareness about its side effects and to certain extent by parental control.

Although, it is stated categorically by WHO, that there are no known consequences on health 
below the limits endorsed by International commission on Non-ionising Radiation Protection (ICNIRP) [1-5]. However, concerns are always raised on the issues of excessive use of mobile phones and their dependency.

The addictive behaviour has been shown by the users which is comparable to compulsive gambling and video gaming, having both physical, psychological withdrawal symptoms when they stop using it like anxiety, restlessness \& irritability [13]. Moreover, self-reported symptoms associated with overuse of mobile phones include headache, earache, sensation of warmth and sometimes difficulties in concentration and fatigue $[7,8]$.

A recently introduced term, Nomophobia, an abbreviation for "no-mobile-phone-phobia" was coined during a 2010 study by UK Post office to look at anxieties suffered by mobile phone users. It included decreased face-to-face interactions, keeping the device in reach when sleeping, looking at phone screen frequently to avoid missing any notifications; also termed as ringxiety $[2,12]$.

Therefore, present study is focused and conducted to determine the pattern of mobile phone usage in undergraduate medical students of PDU Government medical college, Rajkot, Gujarat, India and their perception about harmful effects of mobile phone usage.

\section{MATERIALS AND METHODS}

Study design: Cross-sectional study

Study setting: PDU Government Medical College, Rajkot, Gujarat, India.

Study population: Undergraduate medical students of $1^{\text {st }} \& 2^{\text {nd }}$ year MBBS, PDU Government Medical College, Rajkot, Gujarat, India Sample size: Total 170 undergraduate medical students

Sampling technique: Convenient sampling Duration of study: $4^{\text {th }}$ april-2019 to $8^{\text {th }}$ april2019

Method of data collection: The data was collected by using a pre-formatted and pre-tested structured questionnaire in Google form based on respondent's anonymity. Pre-testing was done, and necessary modifications were made in the questionnaire. The students were approached at the end of lecture class, where they were briefed about the purpose of the study and were invited to participate in study at will. The Google form contained consent form in first section and questionnaire in second section; shared to the students. The link was accessible for 5 days considering the convenience of participants.

Data analysis: Data was entered \& analysed in MS Excel.

\section{RESULTS}

Total 170 students of $1^{\text {st }}$ and $2^{\text {nd }}$ year MBBS, PDU Government Medical College, Rajkot, Gujarat, India responded to the questionnaire shared in Google form for 5 days. In given study group, out of 170 participants $103(60.6 \%)$ were males and $67(39.4 \%)$ were females. All the respondents possessed at least one phone $(97.1 \%)$ and a few had more than one [Figure 1].

It is observed that average time spent by students on mobile phone is 3.75 hours/day [Figure 3]. It is also noted that $87.7 \%$ use $1-1.5$ GB 4G monthly data plan by spending 125-150 rupees for recharge [Table 1]. Out of this data plan, almost half $(47.1 \%)$ of respondents consumed $50-60 \%$ internet data daily [Figure 2].

Table 1: Average Cost of Internet Data Pack Used by Participants.

\begin{tabular}{|c|c|c|c|}
\hline Sr. No. & Data Plan (4G) & $\begin{array}{c}\text { Cost of } \\
\text { Plan/Month (Rs) }\end{array}$ & $\begin{array}{c}\text { No. of } \\
\text { Students }\end{array}$ \\
\hline 1 & $1 \mathrm{~GB} /$ day & 125 & 19 \\
\hline 2 & $1.5 \mathrm{~GB} /$ day & 142 & 130 \\
\hline 3 & $2 \mathrm{~GB} /$ day & 198 & 12 \\
\hline 4 & $3 \mathrm{~GB} /$ day & 299 & 5 \\
\hline 5 & $>3 \mathrm{~GB} /$ day & $>500$ & 4 \\
\hline
\end{tabular}

It was found that $57.6 \%$ parents restrict daily use of mobile phone, majorly possible at home. Meanwhile during the classes, $51.2 \%$ students kept their mobile phones ON. Shockingly $40.6 \%$ and $24.7 \%$ had accepted to receive text messages and play games respectively when in class [Figure 5].

The average daily sleep as stated in the responses was about 6-8 hours by $61.2 \%, 5-6$ hours by $25.9 \%$ and $8-10$ hours by $7.1 \%$ and less than 5 hours for remaining students. $27.6 \%$ felt that their sleep quota is insufficient due to 
Viren B. Kariya, Lalit C. Ratanpara. STUDY THE PATTERN OF MOBILE PHONE USAGE IN MEDICAL STUDENTS.

mobile phones use and $57.6 \%$ still remained satisfied with their sleep. Mobile was majorly kept on table nearby (51.2\%), near pillow/Head $(28.8 \%)$, on bed $(14.1 \%)$ or anywhere while the students were asleep. $75.9 \%$ exhibited the habit of keeping their mobile phones switched on but internet/Wi-Fi OFF and $14.7 \%$ even kept internet/ Wi-Fi ON. Similarly, 55.3\% of students used their mobile phones on urgent basis while on charging.

Fig. 1: Gender Distribution and Availability of Mobile Phones with the Participants.

$$
\text { Your gender }
$$$$
170 \text { responses }
$$

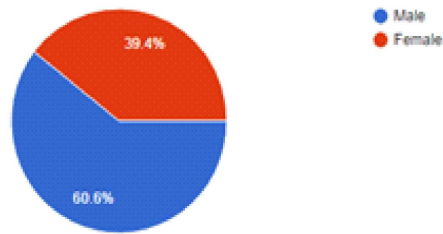

How many mobile phones do you own currently?

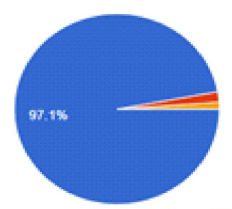

\section{$\because 2$}

Fig. 2: Type of Mobile Recharge Plan and Internet Data Consumption.

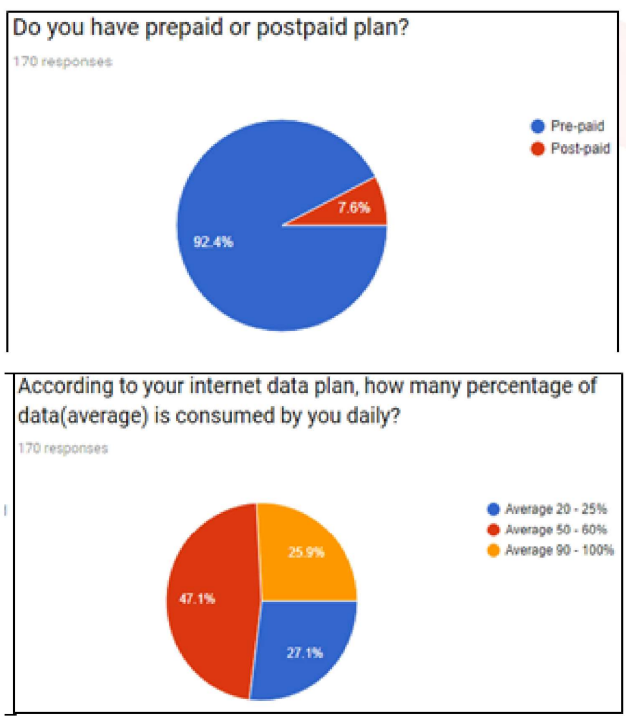

Fig. 3: Daily Usage of Mobile Phones by Participants.

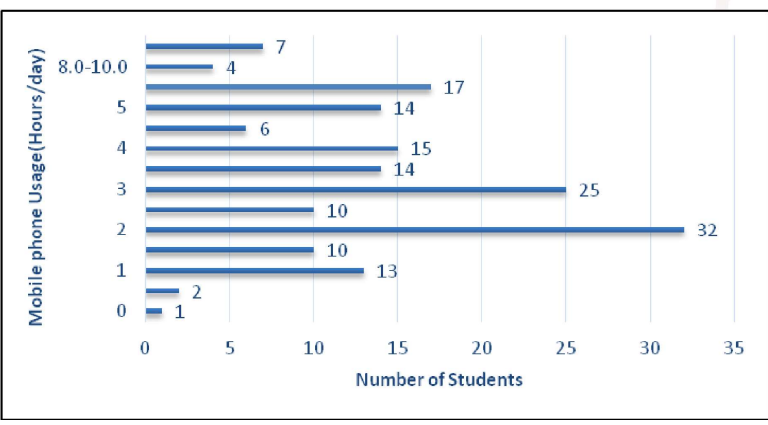

Fig. 4: Use of Phone While Charging and Awareness about Electromagnetic Radiation.
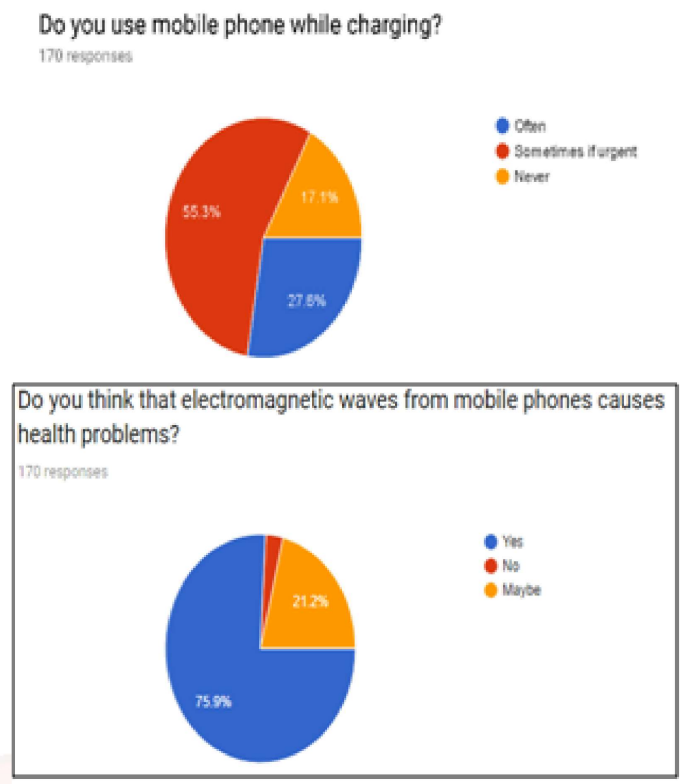

Fig. 5: Percentage of Parental Control and Mobile Use during Class.

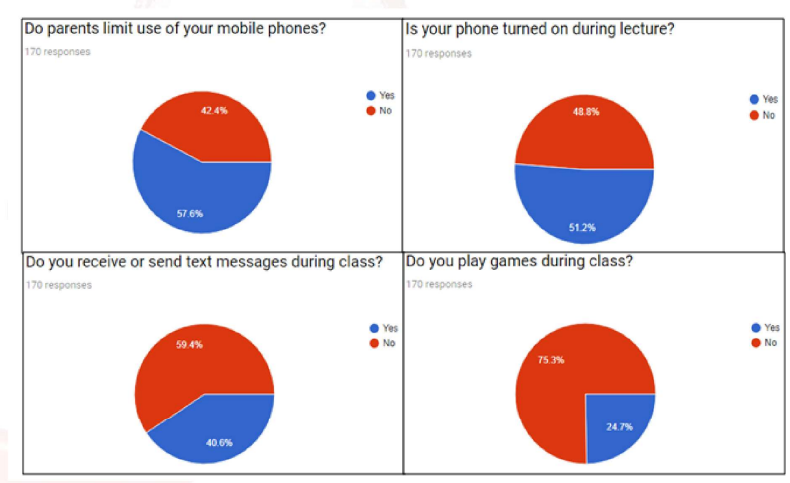

Fig. 6: Effect of Mobile Phones on Sleeping Pattern.

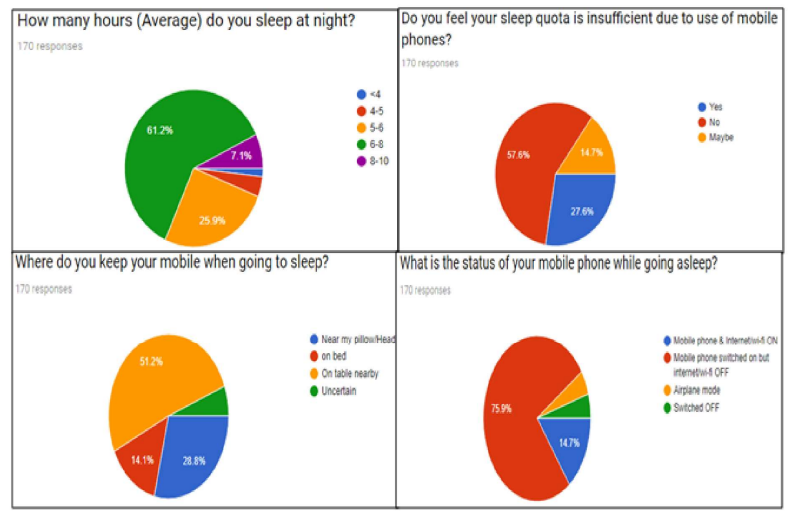

Fig. 7: Where do you keep your mobile while not using?

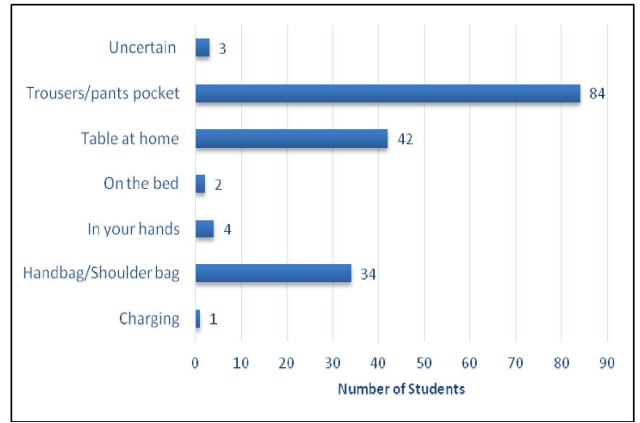


Fig. 8: Awareness of Participants on Health Hazards Associated with Mobile Phone Usage.

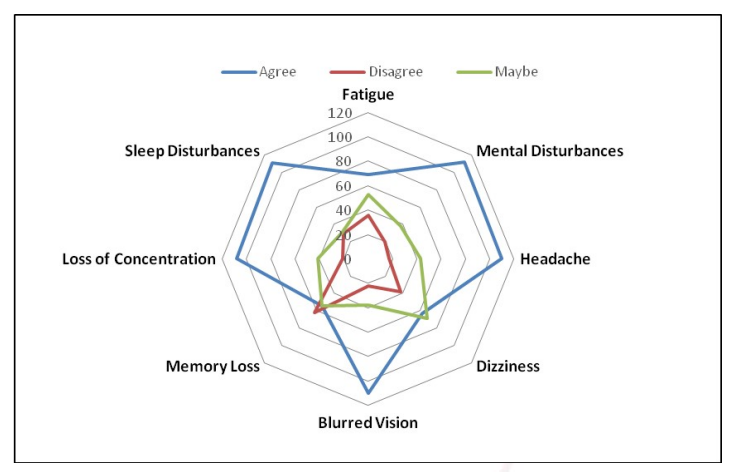

\section{DISCUSSION}

The ownership of smartphone is significantly higher in male $(60.6 \%)$ than in females $(39.4 \%)$ in present study which is in accordance with Bobby Paul et al [1] in undergraduate medical students as well as by Mortazavi et al [10] among junior high school students with significant higher usage among males.

The preferred place of keeping mobile phone while not using is in pockets of trousers (91.6\%) is observed in present study which is quite higher than what reported by Bobby Paul et al [1] in 2014 (71.7\%).

Present study shows average use of mobile phone/day is 3.75 hours (Fig. 3). Datta reported $33 \%$ of the students using their cell phone more than 2 hours/day and he called them as "Very frequent users of cell phone" [3]. Wherever Yadav reported that 65\% students in their study were using smartphone for more than 2 hours/day [14] and Hegazy et al reported 6 hours/day use of mobile phones in Saudi Arabia [6].

It is an interesting observation that $51.2 \%$ of students in present study are keeping their phone ON during classes and apart from that $40.6 \%$ are texting and $24.7 \%$ are playing games during lecture which can be one of the main courses of distraction in their attention which overall affects their academic performance. It is also reported in a similar study by Siddiqi et al [11] in 2017 that $84.5 \%$ students are keeping their mobile phones ON, $65 \%$ are texting and $20 \%$ are playing games during lectures.

In present study, $94.2 \%$ of students spending 125-150 rupees per month to recharge their internet data plan which is much higher (39.5\%) compared to similar study conducted by Sumit data et al[4] in 2016.

It is observed that, $75.9 \%$ of students are keeping their phone ON(but internet OFF) while sleeping and $28.8 \%$ are keep it under the pillow, $14.1 \%$ on bed; which almost similar by Siddiqi et al[11] stating that 70\% keep their mobile ON and $33 \%$ are keeping it under their pillow while going asleep. Keeping it ON entire night; particularly, placing it under the pillow would expose the head part to electromagnetic waves which would create sleep disturbances.

In present study $75.9 \%$ students agree that Electromagnetic waves from mobile phones cause health problems whereas in a similar study conducted by Latha Rajendra Kumar et al [9] in 2011 shows $62 \%$ of students believe and are aware of the side effects of mobile phone usage. Also most of the students were aware of common health hazards like Headache, Sleep disturbances, Loss of concentration and Blurred vision in present study as reported previously.

Limitations: Present study elicits only pattern of usage by respondents but the perception about side effects could have been better studied in longitudinal study.

\section{CONCLUSION AND RECOMMENDATIONS}

Majority of the students in present study use their mobile phone for average 3.75 hours/day. It is also used during classes, while charging and it also remains $O N$ during sleeping hours. Majority of participants are using $1.5 \mathrm{~GB} /$ day data plan which indicate a high usage of internet by medical students. Although mobile phones are essential part of our modern day life, many studies in the past shown that use of mobile phone can turn into overuse and even to the level of enslavement. So, it is recommended that it should be used cautiously and there should be some awareness programme to limit it's unnecessary usage to prevent hazards of electromagnetic waves which can affect not only their health but can also become detrimental to their academics.

\section{Conflicts of Interests: None}

\section{REFERENCES}

[1]. Bobby Paul, Sima Roy. Mobile phone usage pattern among undergraduate medical students at a medical college of Kolkata, west Bengal, India. Turk J public health 2014;12(3):178-187. 
[2]. Bragazzi NL, Puenete GD. A proposal for including nomophobia in the new DSM-V. Psychology Research and Behavior Management 2014;7:155-160.

[3]. Data S, Nelson V, Simon S. Mobile phone use pattern and self-reported health problems among medical students. J Evolution Med Dent Sci. 2016;5:1116119.

[4]. Datta S, Nelson V, Simon S. Mobile phone use pattern and self-reported health problems among medical students. J. Evolution Med. Dent. Sci. 2016;5(21):1116-1119, DOI: 10.14260/jemds/2016/ 259.

[5]. Electromagnetic Fields (EMF) standard and guidelines. World health organization. Available from: http//who.int/peh-emf/standards/en.

[6]. Hegazy AA, Alkhail BA, Awadalla NJ, Qadi M, AlAhmadi J. Mobile phone use and risk of adverse health impact among medical students in Jeddah, Saudi Arabia. BJMMR, 2016;15: 1-11.

[7]. Johansson A, Nordin S, Heiden M, et al. Symptoms, personality traits and stress in people with mobile phone-related symptoms and electromagnetic hypersensitivity. Journal of Psychosomatic Research 2010;68(1):37-45.

[8]. Korpinen LH, Pääkkönen RJ. Self-report of physical symptoms associated with using mobile phones and other electrical devices. Bioelectromagnetics 2009;30(6):431-437.
[9]. Latha Rajendra Kumar, Kiu Dawn Chii. Awareness of mobile phone hazards among university students in a malaysian medical school. 2011;3(7):406-415. doi:10.4236/health.2011.37068.

[10]. Mortazavi SMJ, Atefi M, Kholghi F. The Pattern of Mobile Phone Use and Prevalence of Self-Reported Symptoms in Elementary and Junior High School Students in Shiraz, Iran. Iran J Med Sci 2011;36(2):96-103.

[11]. Najam Siddiqi, Firdous Jahan. Excessive use of mobile phones by medical students: Should precautions be taken? Biomed. \& Pharmacol. J. 2017;10(4):1631-1638.

[12]. Nomophobia is the fear of being out of mobile phone contact-and it's the plague of our $24 / 7$ age. Evening Standard. April 1, 2008. Retrieved 2011-08-10.

[13]. Puente MP, Balmori A. Addiction to cell phones: are there neurophysiological mechanisms involved? Proyecto 2007;61:8-12.

[14]. Yadav UJ, Yadav JD, Study of mobile usage in medical students of deemed university of Western Maharashtra, India. International Journal of Community Medicine and Public Health, 2017;4(2):405408.

How to cite this article:

Viren B. Kariya, Lalit C. Ratanpara. STUDY THE PATTERN OF MOBILE PHONE USAGE IN MEDICAL STUDENTS. Int J Anat Res 2019;7(3.1):6717-6721. DOI: 10.16965/ijar.2019.204 